\title{
Mitragyna ciliata and its trypanocidal activity
}

\section{Ogbunugafor Henrietta, A. ${ }^{1 \star}$ Okochi Veronica, I. ${ }^{2}$ Okpuzor $\mathrm{Joy}^{3}$, Adedayo Titilayo ${ }^{3}$ and Esue Stephen ${ }^{3}$}

\author{
${ }^{1}$ Department of Applied Biochemistry, Nnamdi Azikiwe, University, Awka, Anambra State, Nigeria. \\ ${ }^{2}$ Department of Biochemistry, College of Medicine, University of Lagos, Idi-Araba. Lagos State, Nigeria. \\ ${ }^{3}$ Department of Cell Biology and Genetics, Faculty of Science, University of Lagos, Akoka-Yaba, Lagos State, \\ Nigeria.
}

Accepted 16 May, 2007

\begin{abstract}
The trypanocidal activity of different fractions of hydroethanolic root extract of Mitragyna ciliata Aubrev and Pellegr (Rubiaceae) were evaluated in rats infected with Trypanosoma brucei field isolates from a cow. Oral administration of the fractions at a dose of $100 \mathrm{mg} / \mathrm{kg}$ for 5 days (10 days post-infection) indicated that only butanol fraction showed trypanocidal activity with inhibition percent of 68.68 . The activities of oxidative stress enzymes; superoxide dismutase (SOD) and catalase in the infected rats were determined. SOD activity was significantly higher than control $(1.64 \pm 0.026 \mathrm{I} / \mathrm{U})$ in all fractions except ethyl acetate $(1.56 \pm 0.031 \mathrm{l} / \mathrm{U})$. Catalase showed a significant decrease in activity in butanol $(2.05$ $\pm 0.015 \mathrm{I} / \mathrm{U})$ and chloroform $(2.18 \pm 0.061 \mathrm{l} / \mathrm{U})$ fractions compared to control $(2.30 \pm 0.015 \mathrm{I} / \mathrm{U})$. Butanol fraction might have affected the redox equilibrium of the infected animals causing oxidative stress to the parasites. This is the basis of inhibition of growth of the parasites by the butanol fraction.
\end{abstract}

Key words: Mitragyna ciliata, Trypanosoma brucei, oxidative stress, catalase and superoxide dismutase.

\section{INTRODUCTION}

Trypanosomiasis has recently become resurgent in Africa (WHO, 1998). This disease, restricted to Africa afflicts both human and livestock and causes great social and economic losses. World Health Organisation reports that 66 million people in 36 African countries are afflicted and animal trypanosomiasis causes the death of 3 million cattle each year (WHO, 1998; Truc, 2003). Chemotherapy remains the principal means of control with existing trypanocides being faced with toxicity and drug resistance problems (FAO, 1998). Consequently, this scourge has become a pressing challenge especially to African medical scientists to find an alternative to synthetic drugs for the management of the disease. This has lead to intensive research into African medicinal plants and many of these plants have been found to have antitrypanosomal activity (Atawodi et al., 2003; Freiburghaus et al., 1997; Nok et al., 1993).

Mitragyna ciliata stem bark extract mixed with Garcinia

${ }^{\star}$ Corresponding author. E-mail: tetresearch@yahoo.com. Tel: 08032322729. kola is used for the treatment of trypanosomiasis in traditional medicine in South Eastern Nigeria (Iwu, 1993). The genus Mitragyna has been reported to be rich in alkaloids and many have been isolated from the leaves, stem and root bark. Isolated alkaloids include mitraphylline, rotundifoline, rhynchophyline and speciociliatine (Dongmo et al., 2004). The alkaloids from Mitragyna inermis have been shown to possess in vitro antiproliferative activity against Plasmodium falciparium (Traore et al., 2000). We had earlier reported that the ethanolic root bark extract of this plant possess trypanocidal activity (Ogbunugafor et al., 2005). In this present study, the effect of the fractions of hydroethanolic extract of $M$. ciliata on parasiteamia levels and on oxidative stress enzymes were evaluated in rats infected with $T$. brucei field isolates.

\section{MATERIALS AND METHODS}

Chemicals and solvents

All chemicals and solvents used were of analytical grade and were supplied by Sigma-Aldrich Limited Germany. The reference drug 
Somorenil - diminazine diaceturate was purchased from Damax Agrochemical Company, Agege, Lagos.

\section{Plant preparation}

The fresh root of the plant was collected and authenticated at the Forestry Research Institute (FRIN) Ibadan, Nigeria, by Mr. Felix Isang and Mr. T. K. Odewo, respectively. Plant specimen with No. FHI:106999 M. ciliata Aubrex Pellerg (Rubiaceae local name Abura) was deposited at the FRIN herbarium.

\section{Extraction and fractionation of plant material}

Three hundred grams of air-dried powdered roots was extracted with ethanol/ $\mathrm{H}_{2} \mathrm{O}(8: 2)$ by soaking for $72 \mathrm{~h}$ (3 days) at room temperature. This process was repeated several times to remove the extractable components. Combined extracts was evaporated to dryness under reduced pressure below $40^{\circ} \mathrm{C}$ (yield $20.34 \mathrm{~g}$ ). The extract was fractionated by the method reported by $\mathrm{Wu}$ et al. (2005). The ethanolic extract was dissolved in $200 \mathrm{ml}$ of $\mathrm{MeOH} . \mathrm{H}_{2}$ $\mathrm{O}$ (9.1) mixture and shaken with petroleum ether $(3 \times 100 \mathrm{ml})$. Combined petroleum ether extract was evaporated under reduced pressure to yield 'Pet ether fraction' $(4.16 \mathrm{~g})$. $\mathrm{MeOH}$ was evaporated from the remaining extract and diluted with distilled $\mathrm{H}_{2} \mathrm{O}$ to $200 \mathrm{ml}$ and further fractionated by successive solvent extraction with chloroform $(4 \times 100 \mathrm{ml})$, ethyl acetate $(2 \times 100 \mathrm{ml})$ and $\mathrm{n}$ butanol saturated with $\mathrm{H}_{2} \mathrm{O}(3 \times 100 \mathrm{ml})$. Each extract was evaporated to dryness under reduced pressure to yield ' $\mathrm{CHCl}_{3} \mathrm{fr}^{\prime}$ ' (5.59 g) 'EtOAc fr' $(6.90 \mathrm{~g})$, 'BuOH fr' $(1.46 \mathrm{~g})$ and 'remaining $\mathrm{H}_{2} \mathrm{O}$ $\mathrm{fr}^{\prime}(2.0 \mathrm{~g})$.

\section{Parasites and animals}

Parasites $T$. brucei were obtained from field isolates at the Department of Veterinary Parasitology and Entomology, University of Nigeria Nsukka. They were maintained by continuous passaging in the laboratory until needed. Thirty-five Wistar rats of mixed sexes, weighing between $200-250 \mathrm{~g}$ purchased from the animal house of College of Medicine. University of Lagos, were used for the experiment. The rats were sorted and grouped into 7 groups of 5 rats each and were acclimatised for 2 weeks.

\section{In vivo antitrypanosomal evaluation of fractions}

The grouped rats were inoculated with $10^{6}$ trypanosomes per $\mathrm{ml}$ of blood intraperitoneally using phosphate buffer saline as diluent. Two groups served as positive (reference drug) and negative (untreated) controls. The positive control group were administered with Somorenil - diminazine diaceturate. Five groups served as the test groups and were administered with petroleum ether, chloroform, ethyl acetate, n-butanol, and water fractions. The fractions were dissolved in 5\% carboxy methyl cellulose (CMC) serving as dosing vehicle.

The fractions were administered orally with the aid of oral cannular, to the infected rats at a dose of $100 \mathrm{mg} / \mathrm{kg}$ for 5 days. Reference drug was administered at $3.5 \mathrm{mg} / \mathrm{kg}$ also for five days. Parasiteamia levels were monitored for 28 days or until death of the rats and were estimated by Rapid Matching Method of Herbert and Lumsden (1976). Parasiteamia levels were compared with untreated control animals and percent inhibition of parasites assessed by the formula 100 - [parasiteamia of test / parasiteamia of untreated $x$ 100]. Assessment of the fractions was also based on survival periods of the animals.

\section{Free radical scavenging activity}

The scavenging activity of 1,1-diphenyl-2-picrylhydrazyl (DPPH) free radical by $M$. ciliata extract was determined according to the method reported by Gyamfi et al. (1999). M. ciliata ethanolic extract in methanol $(50 \mu \mathrm{l})$, yielding a series of extract concentrations of $0.02,0.04,0.08$ and $0.1 \mu \mathrm{g} / \mathrm{ml}$, respectively were prepared. Each reaction was mixed with $100 \mu \mathrm{L}$ of $0.1 \mathrm{mM}$ DPPH-ethanol solution and $450 \mu \mathrm{L}$ of $50 \mathrm{mM}$ Tris- $\mathrm{HCl}$ buffer $(\mathrm{pH} 7.4)$. Methanol $(50 \mu \mathrm{L})$ alone was used as control of this experiment. After $30 \mathrm{~min}$ of incubation at room temperature the reduction of the DPPH free radical was measured by reading the absorbance at $517 \mathrm{~nm}$.

Vitamin $E$ was used as positive control. The inhibition ratio (percent) was calculated from the following equation: \%inhibition = [(absorbance of control- absorbance of test sample)/absorbance of control] $\times 100$.

\section{Serum collection}

Tail blood $(2 \mathrm{ml})$ was collected from the rats after administration of fractions and serum separated by centrifugation. Enzyme assay was carried out immediately and was done in triplicate.

\section{Determination of catalase}

Serum catalase activity was determined according to Beers and Sizer (1952) by measuring the decrease in absorbance at $240 \mathrm{~nm}$ in a UV recording spectrophotometer by monitoring the decomposition of $\mathrm{H}_{2} \mathrm{O}_{2}$ as described by Aebi (1984). The reaction mixture (3 $\mathrm{ml}$ vol) contained $0.1 \mathrm{ml}$ of serum in phosphate buffer $(50 \mathrm{mM}, \mathrm{pH}$ 7.0) and $2.9 \mathrm{ml}$ of $30 \mathrm{mM} \mathrm{H}_{2} \mathrm{O}_{2}$ in phosphate buffer $\mathrm{pH}$ 7.0. An extinction coefficient for $\mathrm{H}_{2} \mathrm{O}_{2}$ at $240 \mathrm{~nm}$ of $40.0 \mathrm{M}^{-1} \mathrm{~cm}^{-1}$ Aebi (1984) was used for the calculation. The specific activity of catalase is expressed as moles of $\mathrm{H}_{2} \mathrm{O}_{2}$ reduced per minute per mg protein.

\section{Determination of superoxide dismutase (SOD)}

Whole blood superoxide dismutase was assayed utilizing the technique of Fridovich (1989). $1 \mathrm{ml}$ of whole blood was diluted in 9 $\mathrm{ml}$ of distilled water to make a one in ten dilution of whole blood. An aliquot of $2.0 \mathrm{ml}$ of the diluted blood was added to $2.5 \mathrm{ml}$ of $0.05 \mathrm{M}$ carbonate buffer ( $\mathrm{pH} \mathrm{10.2)} \mathrm{and} \mathrm{left} \mathrm{to} \mathrm{equilibrate} \mathrm{in} \mathrm{the} \mathrm{spectro-}$ photometer. The reaction was started by the addition of $0.3 \mathrm{ml}$ freshly prepared $0.3 \mathrm{mM}$ adrenaline to the mixture which was quickly mixed by inversion. The reference cuvette contained $2.5 \mathrm{ml}$ buffer, $0.3 \mathrm{ml}$ of substrate (adrenaline) and $0.2 \mathrm{ml}$ of water. The increase in absorbance at $480 \mathrm{~nm}$ was monitored every $30 \mathrm{~s}$ for $150 \mathrm{~s}$. A single unit of enzyme is defined as moles of SOD required to produce $50 \%$ inhibition of autoxidation.

\section{RESULTS AND DISCUSSION}

The activity-guided fractionation of hydroethanolic root extract of $M$. ciliata revealed the butanol fraction as possessing the trypanocidal activity credited to this plant (Ogbunugafor et al., 2005) (Table 2). This fraction inhibited the growth of $T$. brucei field isolates by $68.68 \%$ at the end of 5 days oral administration. The inhibition was quite comparable to diminazine diaceturate (the reference drug) which produced complete inhibition (Table 3). 
Table 1. Scavenging activity of 1,1-diphenyl-2picrylhydrazyl (DPPH) free radical by $M$. ciliata extract.

\begin{tabular}{|c|c|c|}
\hline \multirow{2}{*}{$\begin{array}{c}\text { Concentration } \\
(\boldsymbol{\mu g} / \mathbf{~ m L})\end{array}$} & \multicolumn{2}{|c|}{ Percent inhibition } \\
\cline { 2 - 3 } & Control (Vitamin E) & Mitragyna ciliata $^{*}$ \\
\hline 00.02 & $62.20 \pm 0.624$ & $06.96 \pm 0.054$ \\
0.04 & $88.93 \pm 0.423$ & $14.71 \pm 0.046$ \\
0.08 & $89.93 \pm 0.552$ & $53.20 \pm 0.227$ \\
0.10 & $90.29 \pm 0.320$ & $34.21 \pm 0.034$ \\
\hline
\end{tabular}

*significantly lower $(p>0.05)$.

Table 2. Parasiteamia levels in infected rats treated with fractions of Mitragyna ciliata.

\begin{tabular}{|c|c|c|c|c|c|c|c|}
\hline Days & $\begin{array}{c}\text { Untreated } \\
\text { (-ve Control) }\end{array}$ & $\begin{array}{c}\text { Diaceturate } \\
\text { (+ve Control) }\end{array}$ & Butanol & EtOAc & $\mathbf{C H C l}_{\mathbf{3}}$ & Pet Ether & Water \\
\hline $0^{*}$ & $7.01 \pm 0.15$ & $8.21 \pm 0.72$ & $6.28 \pm 0.35$ & $5.09 \pm 0.41$ & $16.44 \pm 4.2$ & $8.48 \pm 2.4$ & $7.88 \pm 2.10$ \\
$3 \#$ & $3.15 \pm 0.04$ & $1.80 \pm 0.02$ & $0.79 \pm 0.04$ & $6.59 \pm 0.25$ & $1.25 \pm 0.02$ & $0.27 \pm 0.03$ & $3.54 \pm 0.25$ \\
$5 \#$ & $2.21 \pm 0.24$ & $0.26 \pm 0.01$ & $0.86 \pm 0.02$ & $0.63 \pm 0.02$ & $3.36 \pm 0.23$ & $4.83 \pm 0.15$ & $6.01 \pm 2.42$ \\
$7 \#$ & $8.00 \pm 1.22$ & $0.00^{+}$ & $2.49 \pm 0.35^{+}$ & $6.10 \pm 0.32$ & $20.04 \pm 8.5$ & $20.30 \pm 9.0$ & $10.45 \pm 3.8$ \\
\hline
\end{tabular}

Values are $\times 10^{6} / \mathrm{ml}$ of blood.

*Before administration of extracts.

\#After administration of extracts.

'significantly lower $(p>0.05)$.

Table 3. Percent inhibition of fractions of Mitragyna ciliata.

\begin{tabular}{|c|c|c|c|c|c|c|}
\hline DAYS & $\begin{array}{c}\text { Diaceturate } \\
\text { (+ve Control) }\end{array}$ & Butanol & EtOAc & $\mathbf{C H C l}_{\mathbf{3}}$ & Pet Ether & Water \\
\hline 3 & 42.86 & 74.82 & -109.20 & 60.65 & 91.40 & -12.83 \\
5 & 88.23 & 53.33 & 71.38 & -52.51 & -118.59 & -172.56 \\
7 & 100.00 & 68.68 & 23.75 & -150.52 & -153.75 & -30.63 \\
Survival \# period (days) & $>28$ & $>28$ & 8 & 5 & 3 & 8 \\
\hline
\end{tabular}

\#After administration of extract.

Table 4. Activities of SOD and catalase in infected rats after administration of fractions of Mitragyna ciliata.

\begin{tabular}{|l|c|c|c|c|c|c|}
\hline Enzyme & Untreated & Butanol & EtOAC & $\mathbf{C H C l}_{3}$ & Pet Ether & Water \\
\hline SOD $(\mathrm{I} / \mathrm{U})$ & $1.64 \pm 0.026$ & $1.73 \pm 0.051^{*}$ & $1.56 \pm 0.03$ & $2.29 \pm 0.04^{*}$ & $2.62 \pm 0.026^{*}$ & $1.85 \pm 0.02^{*}$ \\
Catalase $(\mathrm{I} / \mathrm{U})$ & $2.30 \pm 0.015$ & $2.05 \pm 0.051^{*}$ & $2.33 \pm 0.025$ & $2.18 \pm 0.061^{*}$ & $2.30 \pm 0.04$ & $2.34 \pm 0.015$ \\
\hline
\end{tabular}

*significant $(p>0.05)$.

The effect of the plant extract on the infected animals was evaluated based on the non concentration dependent antioxidative activity of the crude extract (Table 1). The antioxidative activity was significantly lower than control (Vitamin E). Thus, the oxidative stress enzymes superoxide dismutase (SOD) and catalase, of the infected rats were assayed, after oral administration of the fractions. Results showed significantly elevated levels of superoxide dismutase in all fractions, except ethyl acetate (Table 4), indicating an increase in superoxide free radicals in the infected rats (Usoh et al., 2005). The physiological functions of catalase and SOD are well known (Yoruk et al., 2005) we infer that the creation of oxidative stress in the animals will affect the parasites. This is buttressed further in the butanol fraction treated rats which coupled elevated $(p>0.05)$ SOD activity to significantly depressed $(p>0.05)$ activity of catalase (Table 4). Hydrogen peroxide is produced from the dismutation of free oxygen radicals by SOD, even though the natural substrate of catalase acts also as its own inhi- 
bitor (Aksoy et al., 2004). Subsequently, the accumulated $\mathrm{H}_{2} \mathrm{O}_{2}$ alters the redox equilibrium of the animals (increasing oxidative stress) in the butanol fraction treated rats. This seems not to be injurious to the rats but to the parasites resulting in their inhibition. Moreover, superoxide anion inhibits catalase converting it to the feroxyl and ferryl inactive forms of the enzyme (Kono and Fridiwich, 1982). SOD has also been shown to be inactivated by $\mathrm{H}_{2} \mathrm{O}_{2}$ (Rister and Bachner, 1976).

Furthermore, the host (rats) and the trypanosomes have in common superoxide dismutases in their enzymatic defence systems against free radicals (Soulere et al., 1999) but the parasite lacks catalase (Wang et al., 1999). In the absence of catalase the parasite depends solely on a spermidine-gluthathione conjugate named trypanothione whose oxidative form is regenerated by trypanothione reductase that is very sensitive to alteration in redox equilibrium (Atawodi et al., 2003). Therefore, the depression in catalase activity in the infected rats, which arose from its inhibition by accumulated $\mathrm{H}_{2} \mathrm{O}_{2}$, might have caused peroxidative damage to trypanothione reductase. This damage caused disruption in the defence of the parasites against oxidative stress. Consequently, the parasites became vulnerable and their membranes were undermined. The observation that depression in catalase activity coincides with clearance or inhibition of parasites' proliferation is supported by earlier work that $T$. brucei clearance from the blood of Cape buffalo coincided with the time catalase activity was depressed (Wang et al., 1999). In addition, parasitic protozoan are known to be susceptible to free oxygen radical-induced oxidative stress (Clark and Hunt, 1983). Also, our results are consistent with earlier reports that natural products affect their trypanocidal activity by creating oxidative stress (Sepulveda-Boza et al., 1996).

The observation that the activity of SOD was not elevated in the ethyl acetate fraction is consistent with previous studies. Ethyl acetate fraction from various plant extracts is known for its antioxidative property which is attributable to the extractable phenolic compounds in this fraction (Wu et al., 2005).

This report suggests the basis of the trypanocidal activity of the ethanolic root extract of $M$. ciliata and corroborates its use by traditional healers in South Eastern Nigeria for the treatment of trypanosomiasis

\section{ACKNOWLEDGEMENT}

We are grateful to Dr. Ikenna Ezeh of the Department of Veterinary Parasitology and Entomology, University of Nigeria. Nsukka, for technical support.
Aksoy Y, Balk M, Ogus H, Ozer N (2004). The Mechanism of inhibition of human erythrocytes catalase by azide. Turk. J. Biol. 28: 65-70.

Atawodi SE, Bulus T, Ibrahim S, Ameh DA, Nok AJ, Mamman M, Galadima M (2003). In vitro Trypanocidal effect of methanolic extract of some Nigerian Savannah plants. Afr. J. Biotech. 2(9): 317-321.

Beers RF, Sizer IW (1952). A spectrophotometric method for measuring the breakdown of hydrogen peroxide by catalase. J. Biol. Chem. 195: 133-140.

Clark IA, Hunt NH (1983). Evidence for reactive oxygen intermediates causing hemolysis and parasites death in malaria. Infect. Immun. 39(1): 1-6.

Dongmo AB, Kamanyi A, Dzikouk G, Nkeh CB, Tan PV, Nguelefack T, Nole T, Bopolet M, Wagner H (2003). Anti-inflammatory and analgestic props of the stem bark extract of M.ciliata (Rubiaceae) Aubrev \& pellerg. J. Ethnopharmacol. 84: 17-21

Food and Agricultural Organisation (FAO) (1998). Drug management and parasite resistance in Bovine trypanosomiasis pp. 3-10.

Gyamfi MA, Yonamine M, Aniya Y (1999). Free radical scavenging action of medicinal herbs from Ghana: Thomingia sangulnea on experimentally induced liver injuries. Gen. Pharmacol. 32: 661-667.

Freiburghaus F, Jonke SA, Nkunya MH, Mwasumbi LB, Brun R (1997). In vitro trypanocidal activity of some rare Tanzanian medicinal plants. Acta Trop. 67: 181-185.

Fridovich I (1989). Superoxide dismutase: An adaptation to paramagnetic gas. J. Biol. Chem. 254: 7761-7764.

Herbert WJ, Lumsden WH (1976). Trypanosoma brucei: a rapid matching method for estimating the host parasiteamia. Exp. Parasitol. 40: 427-31

Iwu MM (1993). Handbook of African Medicinal plants. CRC Press Inc. pp. 4-10.

Kono Y, Fridiwich I (1982). Superoxide radical inhibits catalase. J. Biol. Chem. 257: 5751-5755.

Nok AJ, Esievo KAN, Arowosafe S, Onyenekwe PC, Gimba CE, Kagbu JA (1993). In vitro activity of leave extracts against Trypanosoma brucei brucei. J. Clin. Biochem. Nutr. 15: 113-118.

Ogbunugafor HA, Okochi VI, Smith HA, Okpuzor J, Ogbonnia S, Emeka $P$, Amadi C (2005). Antitrypanosomal Activity of Mitragyna ciliata and Ritchea longipedicellata. $<$ ABST $>$ P171. $53^{\text {rd }}$ GA Conference Florence. Italy.

Rister M, Bacher R (1976). The alteration of Superoxide dismutase, catalase, gluthathione peroxidase and NADPH cytochrome $\mathrm{C}$ reductase in guinea pig polimorphonuclear leucocytes and alveolar macrophages during hyperoxia. J. Clin. Invest. 58: 1174-1184.

Sepulveda-Boza S, Cassels BK (1996). Plant metabolites active against Trypanosome cruzi. Plant. Med. 62: 98-105.

Soulere L, Hoffmann P, Bringaud F, Perie J (1999). Uptake of NO releasing drugs by the $\mathrm{P} 2$ nucleoside transporters in Trypanosomes. Braz. J. Med. Biol. Res. 32: 1447-1452.

Truc P (2003). About Trypanosome brucei gambiense. The causative form for human African Trypanosomiasis: some findings and proposals. Afr. J. Biotechnol 2(12): 657-661.

Traore F, Gasquet M, Di Giorgio C (2000). Antimalarial activity of four plants used in traditional medicine in Mali. Phytother. Res. 14: 45-47

Usoh IF, Akpan EJ, Etim EO, Farombi EO (2005). Antioxidant Actions of Dried flower extracts of Hibiscus Sabdariffa $L$. on sodium arseniteinduced oxidative stress in rats. Pak. J. Nutr. 4(3): 135-141.

Wang Q, Murphy N, Black SJ (1999). Infection associated decline of Cape Buffallo catalase auguments serum trypanocidal activity. Infect. Immun. 67(6): 2797-2803.

Wu J, Tung Y, Wang S, Shyur L, Kwo Y, Chang S (2005). Phenolic antioxidant from the heartwood of Acacia confusa, J. Agric. Food Chem. 53: 5917-5921.

Yoruk IH, Demir H, Ekici K, Savran A (2005). Purification and properties of catalase from Van apple (Golden Delicious). Pak. J. Nutr. 4(1): 810.

\section{REFERENCES}

Aebi H (1984). Catalase In vitro In: SP Colowick, NO Kaplane (eds). Meth. Enzymol., 105: 121-126. 